\title{
MENINGKATKAN PERILAKU ASERTIF MENGGUNAKAN \\ PENDEKATAN BEHAVIORAL DENGAN LATIHAN ASERTIF PADA SISWA KELAS IX SMP NEGERI 2 SALATIGA
}

\author{
Ertik Indrawati, Setyorini dan Sumardjono Padmomartono \\ Program Studi S1 Bimbingan dan Konseling \\ FKIP - Universitas Kristen Satya Wacana
}

\begin{abstract}
ABSTRAK
Penelitian pretest-posttest control group design ini bertujuan untuk mengetahui signifikansi peningkatan perilaku asertif menggunakan pendekatan behavioral dengan latihan asertif pada siswa kelas IX SMP Negeri 2 Salatiga. Subyek penelitian adalah 10 siswa yang berperilaku asertif sangat rendah dan rendah. Subjek penelitian dibagi menjadi dua kelompok yaitu kelompok eksperimen dan kelompok kontrol, yang tiap kelompoknya terdiri dari 5 siswa. Alat ukur yang digunakan adalah skala perilaku asertif berdasarkan Alberty dan Emmons (Nursalim, 2005). Analisis data untuk menguji perbedaan perilaku asertif siswa menggunakan analisis Mann Whitney. Perbedaan pretest dari kedua kelompok menghasilkan $\mathrm{p}=0,602>0,050$, artinya tidak ada perbedaan signifikan antara kelompok eksperimen dan kelompok kontrol. Dengan demikian eksperimen dapat dilanjutkan. Hasil analisis data setelah posttest, menghasilkan signifikansi perbedaan antara kelompok eksperimen dan kelompok kontrol pada $\mathrm{p}=0,009<0,050$. Dengan demikian dapat disimpulkan bahwa pendekatan behavioral dengan latihan asertif secara signifikan dapat meningkatkan perilaku asertif siswa kelas IX SMP Negeri 2 Salatiga.
\end{abstract}

Kata kunci: Perilaku Asertif, Pendekatan Behavioral, Latihan Asertif

\section{PENDAHULUAN}

Masalah yang dapat timbul dalam diri siswa SMP adalah tidak adanya perilaku tegas (asertif) dalam mengambil keputusan dan mengutarakan hak-haknya sehingga dapat menimbulkan stres yang berakibat kognitif, yaitu mempengaruhi proses berpikir. Akibat kognitif itu muncul dalam bentuk perilaku tidak mampu mengambil keputusan yang sehat, kurang dapat berkonsentrasi, tidak mampu memusatkan perhatian dalam jangka waktu yang lama, sangat peka terhadap kecaman dan mengalami rintangan mental (Siswanto, 2007).

Untuk meningkatkan perilaku asertif dapat digunakan pendekatan behavioral dengan Latihan Asertif. Pendekatan behavioral dipilih karena modifikasi perilaku dalam konseling behavioral menggunakan prinsipprinsip belajar yang telah teruji secara eksperimental untuk mengubah perilaku tidak adaptif. Kebiasaan-kebiasaan yang tidak adaptif dilemahkan dan dihilangkan, perilaku adaptif dimunculkan dan dikukuhkan (Wolpe, dalam Komalasari dkk, 2011). Sedangkan latihan asertif dipilih karena merupakan suatu program untuk mengajar individu mengekspresikan perasaan dan pikirannya secara jujur dan tidak membuat orang lain merasa terancam. Latihan asertif ini digunakan secara kelompok maupun secara individual.

\section{Perilaku Asertif}

Alberti dan Emmons (Nursalim, 2005) menyatakan perilaku asertif mempertim- 
bangkan persamaan hak dalam hubungan antar pribadi; perilaku asertif memungkinkan individu bertindak sesuai dengan kepentingan sendiri dalam mengekspresikan perasaan dengan senang, jujur, menggunakan hak pribadi tanpa mengabaikan hak atau kepentingan orang lain. Dalam perilaku asertif terdapat beberapa aspek yang dikemukakan oleh Alberti dan Emmons dalam 10 kunci pokok perilaku asertif sebagai berikut:

1. Mengekspresikan diri secara penuh.

Artinya individu asertif mampu mengkomunikasikan apa yang diinginkan, dirasakan dan dipikirkan kepada orang lain.

2. Menghormati kepentingan orang lain. Individu asertif dapat menerima keadaan orang lain dengan terbuka tanpa harus memaksakan kehendak kepada orang lain; menunjukkan rasa hormat pada pendapat dan apapun yang dilakukan orang lain terhadapnya.

3. Langsung dan tegas.

Individu asertif mampu mengkomunikasikan pikiran dan perasaan secara langsung, artinya dapat berkomunikasi tanpa perantara orang lain. Selain itu, seseorang dapat dikatakan asertif bila mampu menyatakan keinginan dan sesuatu yang tidak diinginkannya dengan tegas tanpa merasa cemas.

4. Jujur dan terbuka mengatakan kebutuhan, perasaan dan pikiran apa adanya.

Aspek ini menyebutkan individu asertif mampu mengatakan perasaan dan pikirannya apa adanya. Individu bertindak dengan jujur dan terbuka tanpa merasa malu dan takut.

5. Menempatkan orang lain setara dalam suatu hubungan.

Tiap individu tidak dapat hidup tanpa orang lain dan membutuhkan bantuan orang lain. Individu yang asertif dapat menempatkan orang lain setara dengan dirinya tanpa merendahkan orang lain dalam suatu hubungan.

6. Verbal, berisi pesan (perasaan, fakta, pendapat, permintaan, batasan-batasan).

Individu asertif mampu mengekspresikan diri melalui perkataan yang diucapkan. Namun, sesuatu yang diucapkan tidak hanya sebatas mengeluarkan kata-kata saja tapi juga mengandung pesan yang dapat dimengerti oleh lawan komunikasinya. Pesan tersebut berupa perasaan di mana individu dapat mengutarakan perasaannya secara jujur tanpa merasa cemas. Pesan berisi fakta yang terjadi, individu mampu mengatakan kalimat permintaan untuk mengungkapkan kebutuhannya dan yang terakhir adalah batasan-batasan yang mana apapun yang dikatakan individu asertif mempertimbangkan isi kalimat sehingga tidak membuat lawan bicara menjadi terancam.

7. Non verbal, mengandung bentuk pesan (kontak mata, suara, postur, ekpresi wajah, gerak tubuh, jarak fisik, waktu, kelancaran bicara, mendengarkan).

Dalam melakukan proses komunikasi, individu asertif tidak hanya mengutarakan maksud hati secara verbal namun juga non verbal di mana bentuk pesan disertai dengan bahasa tubuh. Orang yang non asertif akan cenderung menunduk atau melihat objek lain daripada melihat mata lawan bicaranya sehingga akan terlihat menunduk atau memalingkan wajah. Lain halnya dengan individu asertif dapat menatap mata lawan bicara disertai dengan intonasi suara yang tepat artinya tidak terlalu lantang dan tidak terlalu lirih. Selain itu mengatur kelancaran bicaranya sehingga tidak gugup atau terbata-bata. Individu asertif menjaga keseimbangan postur tubuh, gerak tubuh, jarak fisik 
dengan lawan bicaranya sekaligus menjadi pendengar yang baik.

8. Layak bagi orang lain dan situasi, tidak universal.

Individu asertif dapat memposisikan diri sesuai dengan keadaan, mampu membedakan cara-cara komunikasi dengan menyesuaikan keadaan dan kondisi lawan bicara.

9. Dapat diterima secara sosial.

Individu asertif adalah individu yang fleksibel yang dapat mengekspresikan diri serta menghormati orang lain sehingga dapat diterima oleh lingkungan sosial, misalnya keluarga, teman, sahabat dan masyarakat pada umumnya. Hal ini bertujuan untuk dapat berkontribusi pada lingkungan sekitar.

10. Perilaku asertif merupakan sesuatu yang dipelajari, bukan bakat yang diturunkan.

Tiap individu terlahir seperti kertas putih yang kosong. Itu berarti perilaku asertif juga dapat dituangkan di dalamnya dengan cara belajar dan berlatih untuk menjadi asertif. Jadi, asertif bukanlah bakat atau keturunan.

Berdasarkan uraian di atas disimpulkan bahwa perilaku asertif yaitu perilaku individu yang dapat mengekspresikan hak, pendapat maupun keinginannya, baik secara verbal atau non verbal. Individu mampu berbicara dengan nada dan volume yang layak, melihat ke arah lawan bicara, melihat dirinya sama dengan orang lain dan tidak menyakiti dirinya untuk tidak menyakiti orang lain. Dengan kata lain, perilaku asertif memperkembangkan persamaan hak dalam hubungan antar individu, memungkinkan individu bertindak sesuai dengan kepentingan sendiri, bertindak bebas tanpa merasa cemas, mengekspresikan perasaan dengan senang dan jujur, menggunakan hak pribadi tanpa mengabaikan hak atau kepentingan orang lain.

\section{Pendekatan Behavioral}

Pendekatan behavior adalah prosedur pengubahan perilaku yang diselenggarakan secara langsung, seketika dan sistematik terutama dalam konteks belajar dan pengelolaan perilaku siswa. Justru sifatnya yang langsung dan seketika inilah maka orang tua dan pendidik perlu lebih dituntut berhati-hati melaksanakan pengubahan terhadap perilaku individu. Konsep behavior modification/ pengubahan perilaku adalah prosedur yang berlaku dalam bimbingan konseling dan psikoterapi; yang di tangan ahlinya masih dikritik karena bernuansa mekanistik dan kurang manusiawi menurut pandangan para humanis. Kontroversi penggunaan prosedur pengubahan perilaku dalam pendidikan mestinya tidak perlu terjadi asalkan pemakainya senantiasa menyadari implikasinya pada perkembangan individu.

Konseling behavioral merupakan satu jenis konseling yang berorientasikan perilaku, bertujuan untuk menghilangkan perilaku yang tidak benar dan membantu konseli menguasai keterampilan-keterampilan atau perilaku-perilaku baru (Loekmono, 2008). Konseling behavioral dikenal juga dengan modifikasi perilaku yang dapat diartikan sebagai tindakan yang bertujuan untuk mengubah perilaku.

Modifikasi perilaku memiliki kelebihan dalam menangani masalah-masalah yang dialami oleh individu (Komalasari dkk, 2011), yaitu dapat merencanakan langkah terlebih dahulu, perincian pelaksanaan dapat diubah menyesuaikan kebutuhan konseli, dapat dievaluasi; teknik konseling dapat dijelaskan dan diatur secara rasional serta dapat diprediksi dan dievaluasi secara obyektif, waktu yang dibutuhkan lebih singkat. Tujuan utama konseling behavioral adalah menyediakan keadaan-keadaan dan ling- 
kungan-lingkungan agar perilaku yang tidak sesuai dapat dihapuskan dan sesudah itu konseli akan diajar untuk menguasai perilaku baru yang sesuai untuk menggantikan perilaku yang tidak sesuai itu.

\section{Latihan Asertif}

Alberty dan Emmons (Nelson-Jones, 2011) mengemukakan latihan asertif bukan hanya berfokus pada perilaku verbal, tetapi juga komponen lain seperti kontak mata, postur tubuh, gestur, ekspresi wajah, volume suara, kelancaran dalam berbicara dan pilihan waktu kapan individu mengekspresikan sikap asertifnya. Latihan asertif merupakan strategi bantuan atau terapi, direkomendasikan untuk mengurangi dan menghilangkan gangguan kecemasan dan meningkatkan kemampuan (kompetensi) interpersonal individu.

Loekmono (2008) menyatakan latihan asertif diberikan pada konseli yang tidak dapat melepaskan kemarahannya, tidak sanggup mengatakan "tidak", terlalu tertib dan mudah dimanfaatkan orang lain, tidak dapat menyatakan isi hati dan perasaan serta sukar mengekspresikan respon-respon positif. Latihan asertif cocok diberikan pada individu yang merasa tidak mempunyai hak untuk menyatakan pikiran, kepercayaan dan perasaannya.

Dalam latihan asertif, ada beberapa strategi yang digunakan. Loekmono (2008) mengutarakan enam strategi latihan asertif, yaitu: (1) Pengajaran, konselor menerangkan kepada konseli perilaku yang diharapkannya.

(2) Respon, konselor merespon secara positif dan juga negatif kepada konseli berkaitan dengan perilakunya sesudah diberi pengarahan. (3) Modeling, konselor menunjukkan contoh perilaku kepada konseli yang dilakukan secara spontan atau dengan memakai tayangan audio vidual. (4) Keasyikan, konseli berlatih melalui permainan agar konseli memainkan peran atau perilaku tertentu; kemudian konseli dikritik konselor. (5) Penguatan sosial, dari waktu ke waktu konseli akan diberi pujian. (6) Tugas atau pekerjaan rumah, konseli diberi tugas untuk dikerjakan.

\section{METODE PENELITIAN}

Subjek penelitian ini adalah 10 siswa kelas IX SMP Negeri 2 Salatiga yang memperoleh skor sangat rendah dan rendah pada perilaku asertif. Subyek penelitian dibagi menjadi 2 kelompok yaitu kelompok eksperimen dan kelompok kontrol masingmasing 5 siswa.

\begin{tabular}{cccc}
\multicolumn{4}{c}{ Rancangan Penelitian } \\
\hline Grup & Pretest & Perlakuan & Posttest \\
\hline Eksperimen & $\mathrm{O}^{1}$ & $\mathrm{X}$ & $\mathrm{O}^{2}$ \\
\hline Kontrol & $\mathrm{O}^{3}$ & - & $\mathrm{O}^{4}$ \\
\hline Keterangan: & & \\
$\mathrm{O}^{1}:$ & Pretest tentang perilaku asertif untuk kelompok \\
& eksperimen \\
$\mathrm{O}^{3}$ & $: \begin{array}{l}\text { Pretest tentang perilaku asertif untuk kelompok } \\
\text { kontrol }\end{array}$ \\
$\mathrm{X}$ & $:$ Pemberian latihan asertif \\
- & $:$ Tidak ada pemberian latihan asertif \\
$\mathrm{O}^{2}:$ & Posttest tentang perilaku asertif untuk kelompok \\
& eksperimen \\
$\mathrm{O}^{4}:$ & Posttest tentang perilaku asertif untuk kelompok \\
& kontrol.
\end{tabular}

Alat pengumpul data yang digunakan adalah skala perilaku asertif yang disusun berdasarkan pada aspek-aspek perilaku asertif yang dikemukakan oleh Alberti dan Emmons (Nursalim, 2005). Digunakan uji Mann Whitney untuk menguji signifikansi hipotesis komparatif antara dua kelompok sampel.

Perlakuan yang dikenakan pada kelompok eksperimen menggunakan topik latihan asertif sebagaimana pada Tabel 1 .

\section{Hasil Penelitian}

Dalam penelitian ini, pemberian perlakuan kepada kelompok eksperimen 
diterapkan sebanyak 8 sesi pertemuan dengan berbagai topik latihan. Setelah pemberian perlakuan selesai, skala perilaku asertif yang sama dengan pretest diadministrasikan kembali kepada kedua kelompok untuk mengetahui perbedaan kedua kelompok pada saat posttest. Berikut adalah hasil sebaran pretest dan posttest dari kelompok eksperimen dan kelompok kontrol.
Berdasarkan Tabel 2, dapat dilihat pada pretest kelompok eksperimen, diantara 5 siswa semuanya berperilaku asertif berkategori rendah, sedangkan hasil posttest kelompok eksperimen terdapat 1 siswa berperilaku asertif berkategori sedang dan 4 siswa berperilaku asertif berkategori tinggi. Dengan demikian semua siswa dalam kelompok eksperimen mengalami peningkatan perilaku

Tabel 1 Topik Latihan Asertif

\begin{tabular}{|c|c|c|}
\hline Sesi & Topik & Aspek yang terkandung \\
\hline 1 & Pengenalan Latihan Asertif & Verbal dan Non verbal \\
\hline \multirow[t]{4}{*}{2} & Penyebab Perilaku Kurang Asertif & 1) Mengekspesikan diri secara penuh. \\
\hline & & 2) Jujur dan terbuka. \\
\hline & & 3) Verbal. \\
\hline & & 4) Non verbal. \\
\hline \multirow[t]{6}{*}{3} & Cara-cara Menghormati Orang Lain & 1) Menghormati kepentingan orang lain. \\
\hline & & 2) Langsung dan tegas. \\
\hline & & $\begin{array}{l}\text { 3) Menempatkan orang lain secara setara dalam suatu } \\
\text { hubungan. }\end{array}$ \\
\hline & & 4) Layak bagi orang lain dan situasi. \\
\hline & & 5) Dapat diterima secara sosial. \\
\hline & & 6) Dapat dipelajari. \\
\hline \multirow[t]{6}{*}{4} & Menyampaikan Kalimat Permintaan & 1) Mengekspresikan diri secara penuh. \\
\hline & dan Penolakan & 2) Langsung dan tegas. \\
\hline & & 3) Jujur dan terbuka. \\
\hline & & 4) Verbal. \\
\hline & & 5) Non verbal. \\
\hline & & 6) Dapat dipelajari. \\
\hline \multirow[t]{4}{*}{5} & Bertanya dan Menjawab & 1) Menghormati kepentingan orang lain. \\
\hline & & 2) Verbal. \\
\hline & & 3) Non verbal. \\
\hline & & 4) Dapat dipelajari. \\
\hline \multirow[t]{3}{*}{6} & Aku Punya Ide & 1) Mengekspresikan diri secara penuh \\
\hline & & 2) Verbal \\
\hline & & 3) Non verbal \\
\hline \multirow[t]{4}{*}{7} & Perilaku Asertif dan Non Asertif & 1) Mengekspresikan diri secara penuh. \\
\hline & & 2) Langsung dan tegas. \\
\hline & & 3) Verbal. \\
\hline & & 4) Non verbal. \\
\hline \multirow[t]{11}{*}{8} & Penguatan dan Evaluasi Latihan & 1) Mengekspesikan diri secara penuh. \\
\hline & Asertif & 2) Menghormati kepentingan orang lain. \\
\hline & & 3) Langsung dan tegas. \\
\hline & & 4) Jujur dan terbuka. \\
\hline & & $\begin{array}{l}\text { 5) Menempatkan orang lain secara setara dalam suatu } \\
\text { hubungan. }\end{array}$ \\
\hline & & 6) Verbal. \\
\hline & & 7) Non verbal. \\
\hline & & 8) Layak bagi orang lain dan situasi. \\
\hline & & 9) Dapat diterima secara sosial. \\
\hline & & 10) Dapat diterima secara sosial. \\
\hline & & 11) Dapat dipelajari. \\
\hline
\end{tabular}


asertif. Sedangkan pada pretest kelompok kontrol, dari 5 siswa berperilaku asertif berkategori rendah dan pada posttest kelompok kontrol yang berjumlah 5 siswa semua juga mengalami peningkatan sehingga perilaku asertifnya menjadi berkategori sedang.

Namun, dari hasil analisis data dengan bantuan SPSS Ver. 17.0 for Windows diperoleh $p=$ Asymp. Sig. 0,009<0,050. Penghitungan statistik tersebut menunjukkan ada perbedaan yang signifikan perilaku asertif antara kelompok eksperimen dan kelompok kontrol. Hal ini menunjukkan bahwa latihan asertif secara signifikan efektif untuk meningkatkan perilaku asertif siswa.

Dengan demikian, hipotesis yang diajukan bahwa perilaku asertif dapat ditingkatkan secara signifikan melalui pendekatan behavioral dengan latihan asertif pada siswa SMP Negeri 2 Salatiga, "diterima".

\section{PEMBAHASAN}

Setelah kelompok eksperimen diberi perlakuan dengan latihan asertif selama 8 sesi pertemuan, terjadi perbedaan yang signifikan antara kelompok eksperimen dan kelompok

Tabel 2 Sebaran Skor Perilaku Asertif dari Pretest dan Posttest Kelompok Eksperimen dan Kelompok Kontrol

\begin{tabular}{cccccc}
\hline \multirow{2}{*}{ Interval } & Kategori & \multicolumn{2}{c}{ Kelompok Eksperimen } & \multicolumn{2}{c}{ Kelompok Kontrol } \\
\cline { 3 - 6 } & & Pretest & Posttest & Pretest & Posttest \\
\hline $\mathbf{4 6 - 7 3}$ & Sangat Rendah & 0 & 0 & 0 & 0 \\
\hline $\mathbf{7 4 - 1 0 1}$ & Rendah & 5 & 0 & 5 & 0 \\
\hline $\mathbf{1 0 2 - 1 2 8}$ & Sedang & 0 & 1 & 0 & 5 \\
\hline $\mathbf{1 2 9 - 1 5 6}$ & Tinggi & 0 & 4 & 0 & 0 \\
\hline $\mathbf{1 5 7 - 1 8 4}$ & Sangat Tinggi & 0 & 0 & 0 & 0 \\
\hline & Jumlah & 5 & 5 & 5 & 5 \\
\hline
\end{tabular}

Tabel 3 Perbedaan Mean Rank Kelompok Eksperimen dan Kelompok Kontrol

NPar Tests

Mann-Whitney

\begin{tabular}{|cc|c|c|c|}
\hline \multicolumn{4}{|c|}{ Ranks } \\
\hline \multirow{3}{*}{ Skor } & Kelompok & $\mathrm{N}$ & Mean Rank & Sum of Ranks \\
\hline & Eksperimen & 5 & 8.00 & 40.00 \\
& Kontrol & 5 & 3.00 & 15.00 \\
& Total & 10 & & \\
\hline
\end{tabular}

Tabel 4. Signifikansi Posttest Perilaku Asertif

NPar Test

Mann-Whitney Test

Test Statistics ${ }^{b}$

\begin{tabular}{|l|l|l|}
\hline & Pretest & Posttest \\
\hline Mann-Whitney U & 10.000 & .000 \\
Wilcoxon W & 25.000 & 15.000 \\
$\mathrm{Z}$ & -.522 & -2.611 \\
Asymp. Sig. (2-Tailed) & .690 & .009 \\
\hline
\end{tabular}


kontrol. Perbedaan tersebut dapat dilihat dari hasil posttest dengan nilai $p=$ Asymp. Sig. $0,009<0,050$; serta dapat dilihat pada rerata mean kelompok eksperimen mengalami perbedaan yang signifikan sebelum dan sesudah eksperimen, yaitu 5,00 pada saat sebelum eksperimen dan 8,00 setelah selesai eksperimen.

Terjadinya perbedaan tersebut menunjukkan ada peningkatan secara signifikan perilaku asertif siswa kelas IX SMP Negeri 2 Salatiga melalui latihan asertif. Selain topik yang diberikan berdasarkan dengan permasalahan asertif yang dihadapi siswa, kelompok eksperimen mengikuti latihan asertif dengan antusias, senang dan rajin mengikuti instruksi selama eksperimen, memahami topik yang diberikan dan berlatih untuk menerapkan tiap topik yang dilatihkan dalam kehidupan sehari-hari. Temuan ini sejalan dengan pandangan Alberty dan Emmons (Nursalim, 2005) yang menyatakan latihan asertif dapat digunakan untuk meningkatkan perilaku asertif individu yang pasif/kurang asertif.

Hasil penelitian ini mendukung pula temuan Nurfaizal (2013) "Efektifitas Assertive Training untuk Meningkatkan Perilaku Asertif Siswa SMK Kartika Siliwangi 2 Bandung kelas X" yang menunjukkan bahwa pencapaian hasil perilaku siswa dari yang tertinggi sampai terendah dilihat dari skor aspeknya yaitu siswa memiliki sikap dan pandangan yang aktif terhadap kehidupan, siswa bebas mengemukakan pikiran dan pendapat, siswa mampu menyatakan pikiran dan perasaan dengan tepat, dan siswa mampu berkomunikasi secara langsung, siswa terbuka dan jujur, serta siswa menerima keterbatasan dalam diri. Disimpulkan melalui penelitian tersebut program intervensi berbasis assertive training efektif digunakan untuk meningkatkan perilaku asertif siswa.

\section{KESIMPULAN}

Berdasarkan hasil analisis, maka kesimpulan penelitian ini adalah bahwa perilaku asertif secara signifikan dapat ditingkatkan melalui pendekatan behavioral dengan latihan asertif pada siswa kelas IX SMP Negeri 2 Salatiga, dengan $p=$ Asymp. Sig. 0,009<0,050.

\section{DAFTAR PUSTAKA}

Komalasari, dkk. 2011. Teori dan Teknik Konseling. Jakarta: PT Indeks

Loekmono, J. T. 2008. Model-Model Konseling. Salatiga: Widya Sari.

Nelson, Richard dan Jones. 2011. Teori dan Praktis Konseling dan Terapi. Yogyakarta: Pustaka Pelajar.

Nurfaizal. 2013. Efektifitas Assertive Training untuk Meningkatkan Perilaku Asertif Siswa SMK Kartika Siliwangi 2 Bandung kelas X. Skripsi. Bandung: Universitas Pendidikan Indonesia.

Nursalim, dkk. 2005. Strategi Konseling. UNESA University Press.

Siswanto. 2007. Kesehatan Mental: Konsep, Cakupan dan Perkembangannya. Yogyakarta: Andi Offset. 